\title{
Regularities In The Development Of The Theory Of Energy Efficiency Management
}

\author{
https://doi.org/10.21272/sec.5(1).117-132.2021.
}

Yevheniia Ziabina, ORCID: https://orcid.org/0000-0003-0832-7932

Department of Marketing, Sumy State University, Ukraine

Yevhen Kovalenko, ORCID: https://orcid.org/0000-0002-2111-9372

$\mathrm{PhD}$ in Economics, Senior Lecturer, Department of Economics, Entrepreneurship and Business Administration, Sumy State University, Ukraine

\begin{abstract}
This article summarizes the arguments and counterarguments within the scientific discussion on the laws of developing the theory of energy efficiency management of the national economy. The study's primary purpose is to develop theoretical and methodological tools for analyzing the patterns of development of the theory of energy efficiency management of the national economy. Systematization of literature sources and approaches to solving the problem of developing the idea of energy efficiency management of the national economy has shown a need to update state energy policies, strategies, regulatory and legal support for the energy sector's functioning. The urgency of solving this scientific problem is to intensify research on the development of the national economy's energy efficiency management theory. The research on the laws of development of the theory of energy efficiency management of the national economy in the article is carried out in the following logical sequence: the systematization of literature sources and approaches to study the theory of energy efficiency management of the national economy, bibliometric and trend analysis to further identify basic theoretical principles and stages of energy management theory, the efficiency of the national economy. Methodological tools of the study were methods of logical generalization, comparative analysis and trend and bibliometric analysis - to identify patterns in developing the theory of energy efficiency of the national economy; the study period was chosen from 2000 to 2020. VOSViewer v.1.6.10 toolkit was used for bibliometric analysis, Google Trends for trend analysis. The object of the study is a sample of 48,888 publications and 21,725 search queries for the keywords like energy policy, energy efficiency, sustainable development based on scientometric databases Scopus and Web of Science, as well as Google Trends tools. The article presents the results of trend and bibliometric analysis of the development of energy efficiency management theory of the national economy, which showed that today the relevance and interest in the development of energy efficiency of the national economy is only gaining momentum, primarily due to the transition to a new stage of carbon neutral development.
\end{abstract}

Keywords: energy efficiency, carbon-free economy, sustainable development, energy sector, green energy, energy security.

JEL Classification: P28, O13, P18, P48, Q40.

Cite as: Ziabina, Ye., Kovalenko, Ye. (2021). Regularities In The Development Of The Theory Of Energy Efficiency Management. SocioEconomic Challenges, 5(1), 117-132. https://doi.org/10.21272/sec.5(1).117$\underline{132.2021 .}$

Received: 06.10 .2020

Accepted: 15.12 .2020

Published: 30.03 .2021

Copyright: (C) 2021 by the authors. Licensee Sumy State University, Ukraine. This article is an open access article distributed under the terms and conditions of the Creative Commons Attribution (CC BY) license (https:// creativecommons.org/licenses/by/4.0/). 


\section{Introduction}

Stable and promising development of the national economy is possible with the efficient functioning of the country's energy sector, its maximum independence from imported energy sources and uninterrupted operation. To date, in Ukraine, unfortunately, none of the above conditions are met. Current research areas for the last ten years are: search for alternative ways to reduce energy consumption with constant production capacity, analyse the efficiency of renewable energy sources in levelling traditional energy sources, and analyse energy efficiency as the main determinants of reducing carbon emissions. Thus, our study aims to find relevant working concepts in the energy efficiency management of the national economy for further formation of the idea of transition of the national economy to the model of carbon-neutral development.

\section{Literature Review}

A study of the evolution of the carbon-neutral economy shows that this concept was studied only from a theoretical point of view in the early stages of this concept. Since 2019 it has become a priority for development among all countries. Carbon neutrality implies mass transformation from traditional energy to renewable (alternative) and complete thermal modernization, modification of the production sector in energy-saving and energy efficiency, innovative changes in treatment systems and recycling, etc. A critical engine for developing a carbon-neutral economy in the national economy is a set of mechanisms and tools to increase energy efficiency through innovative sustainable development (Ziabina, 2019; Ziabina, 2021).

It should be noted that the transition to a carbon-neutral economy depends primarily on the efficiency of the energy sector, which is of strategic importance to the country. The problem of increasing the energy efficiency level in Ukraine is one of the essential issues to ensure sustainable innovation development and the country's energy independence. Domestic and scientists from abroad (Pavlyk, 2020; Palienko, Lyulyov, Denysenko, 2017; Taliouris, Trihas, 2017; Molotok, 2020; Palienko, Lyulyov, 2018) pay great attention to the study of the impact of innovation and investment determinants on the development of energy efficiency of the national economy and how the level of energy efficiency of the country affects macroeconomic stability and competitiveness..

I.M. Mazur (Mazur, 2014), in his research, pays attention to the main problems of the development of energyefficient enterprises in the national economy of Ukraine, improving their energy security and maximizing their impact on the environment by increasing energy efficiency.

In particular, today, the scientific community focuses on evolutionary theories of energy efficiency of the national economy in the context of sustainable and carbon-neutral development through bibliometric analysis. Thus, in a scientific publication (De la Cruz-Lovera, Perea-Moreno, de la Cruz-Fernández, Alvarez-Bermejo, \& ManzanoAgugliaro, 2017), the authors conducted a detailed analysis using scientometric databases Scopus and Web of Science and VOSviewer software on the significant contribution of the international community, higher education institutions and scientific societies to the coverage of problems and ways to solve them in the field of sustainable development and energy efficiency in the context of the formation of energy-saving infrastructure.

Accordingly, a large number of scientific papers are devoted to the study of energy efficiency of the national economy (Ziabina, \& Pimonenko, 2020; Gavrilko, Gavrilko, \& Gushtan, 2018; Ziabina, \& Pimonenko, 2020), the study of indicators and determinants that affect it, as well as its methods increase in the context of energy saving and the level of energy security of the country.

Scientific papers (Ziabina, 2014; Komelina, \& Boldyreva, 2019; Tovmasyan, 2019) pay special attention to sustainable development in the promotion of renewable energy sources in the European Union, namely the introduction of carbon-neutral development, considering potential economic, climate and social opportunities of each region in combination with the environmental policy of the European Union.

The authors of the articles (Liulov, Pimonenko, Stoyanets, \& Letunovska, 2019; Lyulyov, \& Pimonenko, 2017) consider the essence of green investing as one of the effective methods of developing a carbon-neutral economy in Ukraine and the world in general. There are such concepts as greenwashing and its features in marketing communications in the process of green investment development. 
Chigrin Olena Yuriyivna, in her works (Chigrin, \& Scherbak, 2011; Pimonenko, Chygryn, \& Luylov, 2018), considers the main trends of global consumption, in particular, green consumption as a systemic and holistic approach that affects the development of renewable energy sources in the world.

Domestic and foreign scientists in their publications (Bozhkova, Ptashchenko, Saher, \& Syhyda, 2018; Chygryn, Bilan, \& Kwilinski, 2020; Korobets, Panchenko, Harust, Us, \& Pavlyk, 2020; Panchenko, Harust, Us, Korobets, \& Pavlyk, 2020; Pimonenko, Lyulyov, \& Chygryn, 2018; Pimonenko, 2018; Pimonenko, \& Lushchik, 2017; Pimonenko, \& Lyulyov, 2019; Pimonenko, 2019; Pimonenko, 2019) actively investigate the impact of marketing determinants on the level of national energy efficiency by increasing interest and promoting green investment both at the level of private households and at the macroeconomic level. These studies reveal the essence of green branding, green investments, and their role in developing energy-efficient and energy-independent state.

The articles of many foreign scientists (Caruso, Colantonio, \& Gattone, 2020; Nasr, Kashan, Maleki, Jafari, \& Hashemi, 2020) explore the main areas of energy efficiency and energy saving through the introduction of solar photovoltaic panels, heating devices, wind turbines, etc.

The authors (Sineviciene, Sotnyk, \& Kubatko, 2017) investigated energy efficiency and energy consumption trends and their trends in Eastern Europe from 1996 to 2013. According to the study results, the dependence of the level of GDP on energy efficiency and energy consumption was established. It is also worth noting the study (He, 2019; Mačaitytè, Virbašiūtè, 2018; Karakasis, 2017), which provides generalized arguments and counterarguments on the impact of institutional factors on the environment and the level of energy security.

In a scientific paper (Uzar, 2020), the authors investigated solar photovoltaic technology's relevance. They presented a five-stage model developed to assess the roof of the house's photovoltaic potential, taking into account geographical, climatic and technical aspects.

It is necessary to note scientific works (El Amri, Boutti, Oulfarsi, Rodhain, Bouzahir, 2020; Khadidja, Bachir, 2018; Kouassi, 2018; Yiu, Saner, Bardy, 2020; Bonamigo, Mendes, 2019) in which the policy in the direction of reduction is investigated, carbon dioxide emissions, as well as the main financial, economic, environmental and social determinants that can both positively and negatively affect the development of a carbon-neutral model in terms of different countries.

\section{Methodology and research methods}

The study of the patterns of development of the theory of energy efficiency management of the national economy took place in several successive stages. The first stage of the research is to identify the search and formation of relevant information in the scientometric databases Scopus and Web of Science and the Google search engine using Google Trends tools. A sample of 48,888 publications and 21,725 search queries (keywords: energy policy, energy efficiency, sustainable development) in the period from 2000 to 2020 was generated for analysis. In the second stage, we use bibliometric analysis with the help of imported data using VOSViewer v.1.6.10 toolkit for trend analysis - Google Trends.

\section{Results}

In the first stage the results of the study of existing scientific papers, indexed by scientometric databases Scopus and Web of Science, show that the most significant scientific output in the number of articles examining the energy efficiency of the national economy in the world was formed in 2014 and to date ( Fig. 1). In 2014, the number of scientific publications devoted to energy efficiency research began to grow. This trend is explained by the irreversible consequences of climate change in the world, as well as the development and approval by the UN General Assembly of the Action Plan "Transforming our world: Agenda for sustainable development until 2030" (https://www.president.gov.ua/documents/7222019-29825). At the end of 2019, the number of scientific publications covering the scientific results of research on the development of energy efficiency increased by $123 \%$ compared to 2014. 


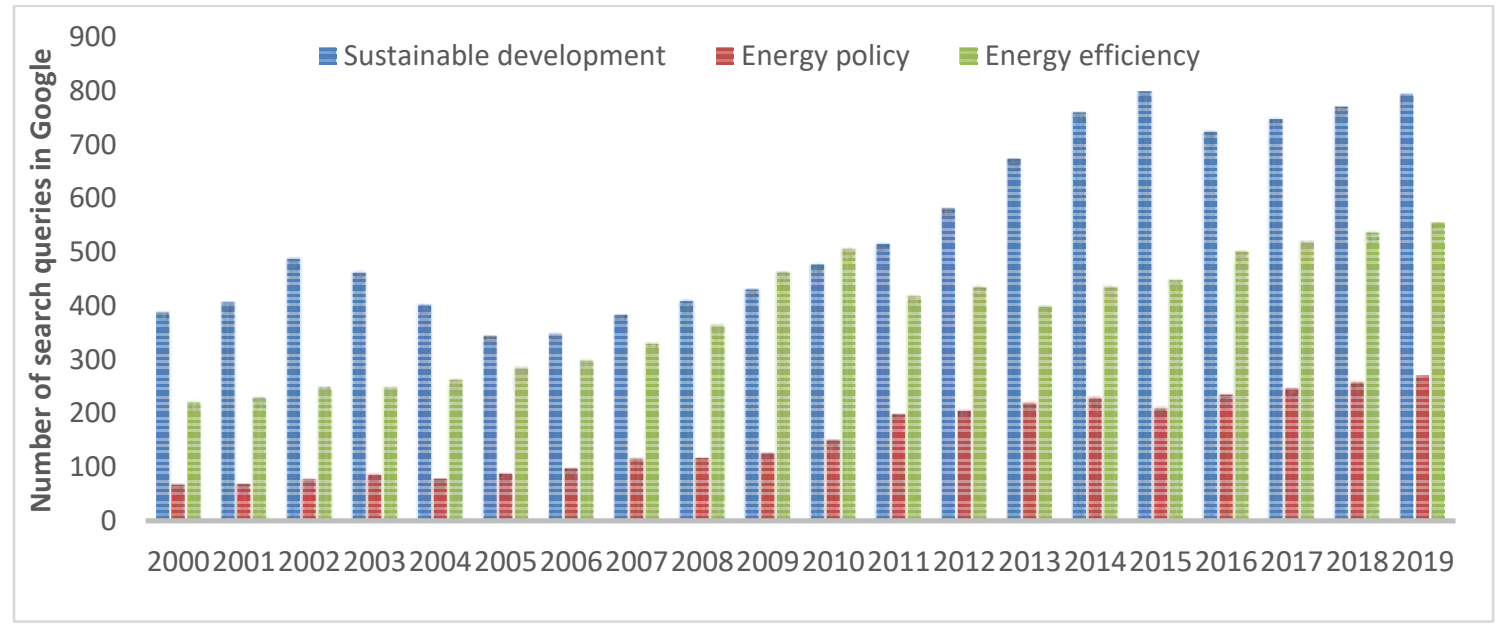

Figure 1. The results of the analysis of the synchronization of trends for search queries "sustainable development", "energy policy", "energy efficiency" in the Google search engine using the Google Trends toolkit

Source: built by the author based on data (Ziabina, 2021) and Google Trends.

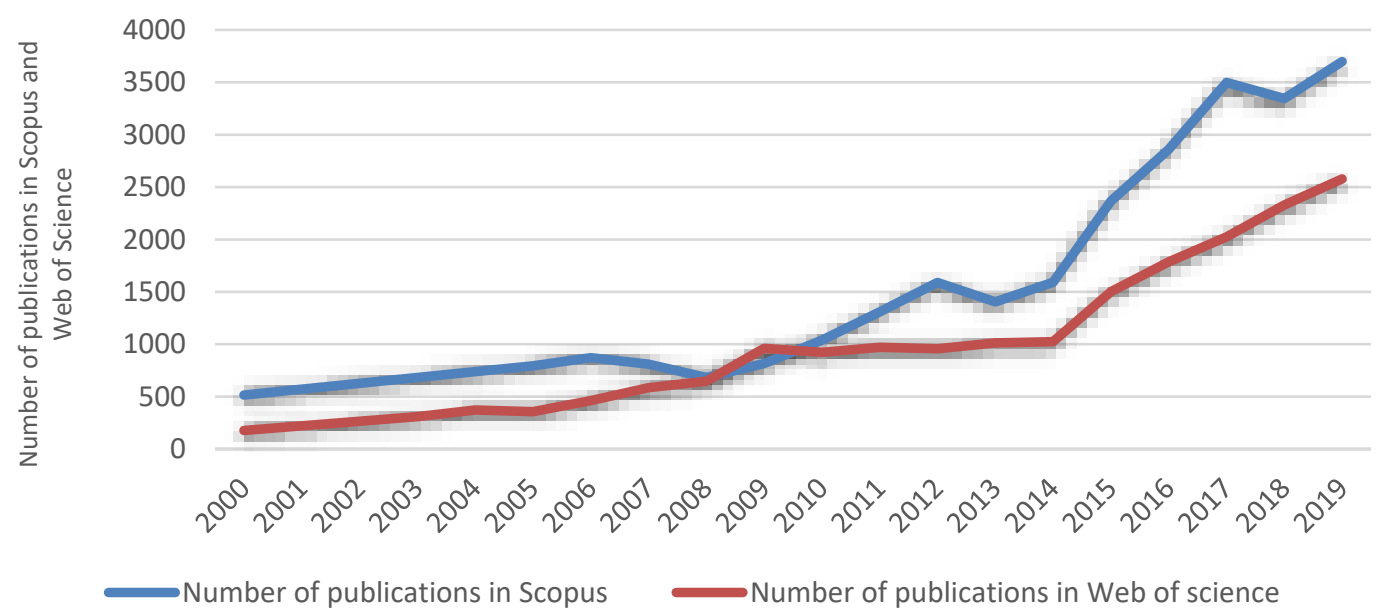

Figure 2. Dynamics of the number of scientific publications devoted to the study of energy efficiency of the national economy, indexed by scientometric databases Scopus and Web of Science

Source: built by the author based on data (Ziabina, 2021) and Scopus та Web of Science.

To study in detail, the change in the level of interest of society and the scientific community on the energy efficiency of the national economy, the frequency of search queries "energy policy", "energy efficiency", "sustainable development" (Figures 1-5) in the Google search engine was analyzed. The Google Trends toolkit was used to generate the relevant information. The results of the study show that the maximum number of requests for the term "energy policy" falls on 2019 (271 requests), for the word "energy efficiency" - for 2019 (554 bids), and the term "sustainable development" - for 2015 ( 799 requests). The corresponding results correlate with each other and confirm the hypothesis of regularity in developing the theory of energy efficiency management of the national economy. 


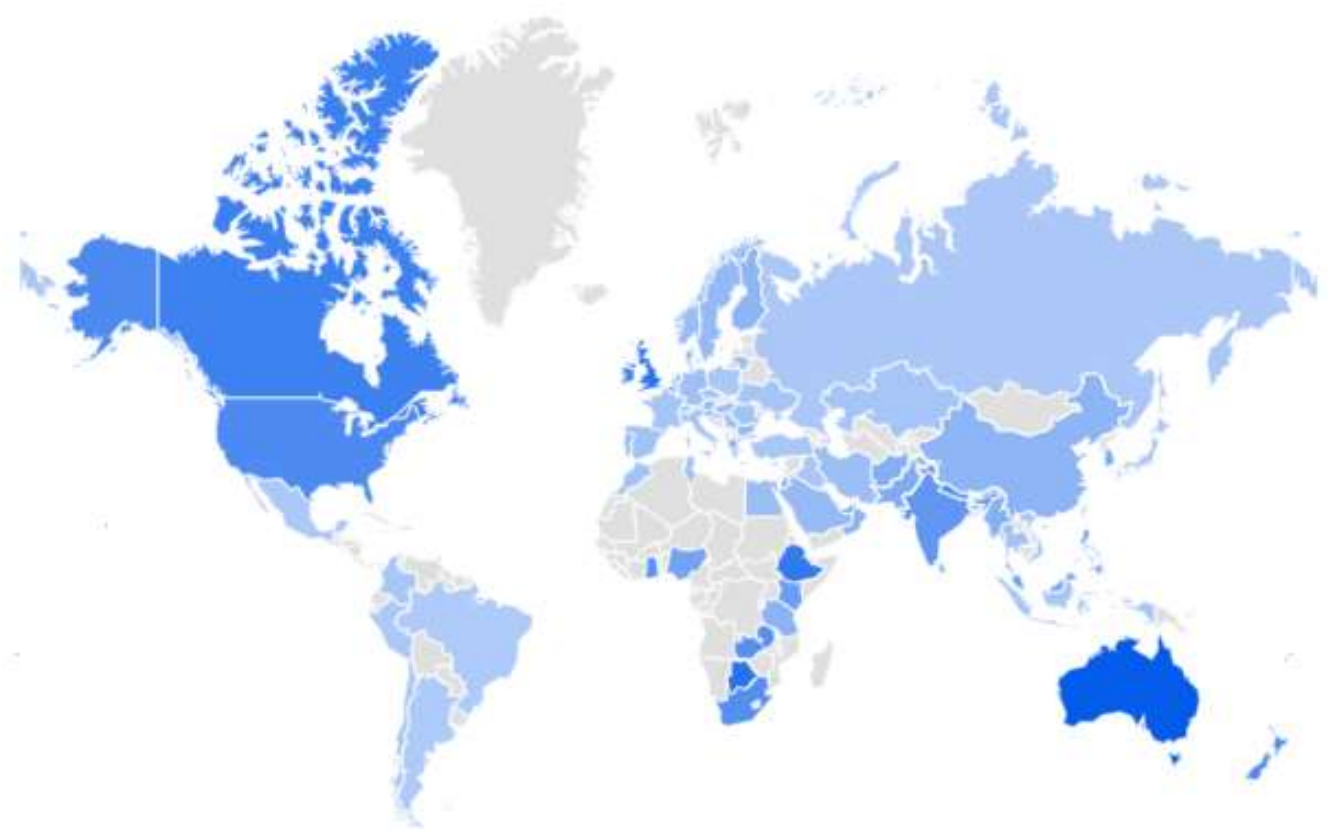

Figure 3. Topographic map of the world, showing the number of requests for the term "energy efficiency" (2004-2019). (Color intensity depends on the percentage of queries)

Source: built by the author based on data (Ziabina, 2021) and Google Trends.

The analysis also identified the top 10 countries most interested in energy efficiency (Table 1). Australia, the United Kingdom, Singapore, Hong Kong, Kanata, Ireland, the United States, New Zealand, South Africa and Cyprus were most interested.

Table 1. The level of interest in the world by term "energy efficiency" (2004-2019)

\begin{tabular}{|c|c|c|}
\hline № & Country & Interest level, $\%$ \\
\hline 1 & Australia & 100 \\
\hline 2 & UK & 80 \\
\hline 3 & Singapore & 78 \\
\hline 4 & Hong Kong & 67 \\
\hline 5 & Canada & 62 \\
\hline 6 & Ireland & 57 \\
\hline 7 & United States & 57 \\
\hline 8 & New Zealand & 53 \\
\hline 9 & The South African Republic & 47 \\
\hline 10 & Cyprus & \\
\hline
\end{tabular}

Source: built by the author based on data (Ziabina, 2021) and Google Trends. 


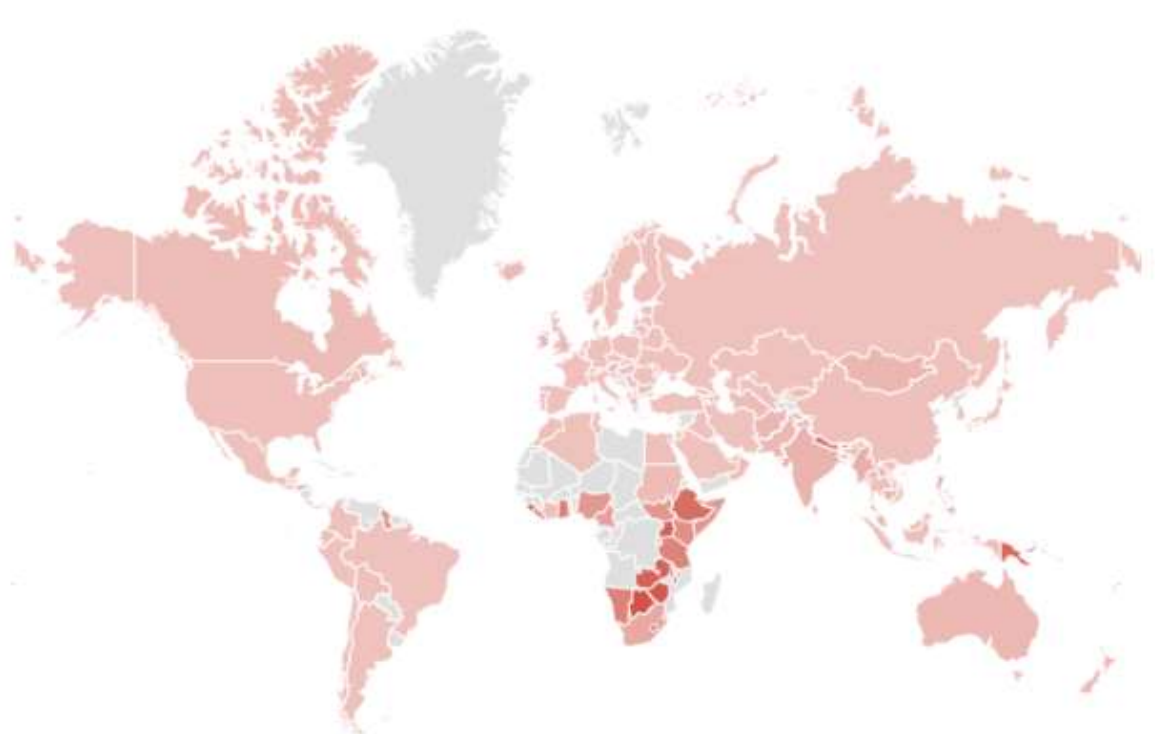

Figure 4. Topographic map of the world, showing the number of queries by term "sustainable development" (2004-2019). (Color intensity depends on the percentage of queries)

Source: built by the author based on data (Ziabina, 2021) and Google Trends.

The study identified the most popular queries for the term "energy efficiency" - energy efficiency, credit for energy efficiency, energy efficiency management, and calculating energy efficiency, energy efficiency ratio and others. These results confirm the relevance of the topic studied by the author.

The analysis also revealed the top 10 countries whose populations are most interested in sustainable development (Table 2). The most curious were Solomon Islands, Lesotho, Bhutan, Malawi, Botswana, Fiji, Eswatini, Zimbabwe, Zambia, and Uganda.

Table 2. The level of interest in the world by term "sustainable development" (2004-2019)

\begin{tabular}{|c|c|c|}
\hline № & Country & Interest level, \% \\
\hline 1 & Solomon Islands & 80 \\
\hline 2 & Lesotho & 79 \\
\hline 3 & Butane & 63 \\
\hline 4 & Malawi & 63 \\
\hline 5 & Botswana & 61 \\
\hline 6 & Fiji & 59 \\
\hline 7 & Eswatini & 59 \\
\hline 8 & Zimbabwe & 55 \\
\hline 9 & Zambia & 55 \\
\hline
\end{tabular}

Source: built by the author based on data (Ziabina, 2021) and Google Trends.

The study results revealed the most popular queries for the term "sustainable development" - sustainable development goals, UN sustainable development goals, sustainable development in India, what is sustainable development, the importance of sustainable development. 


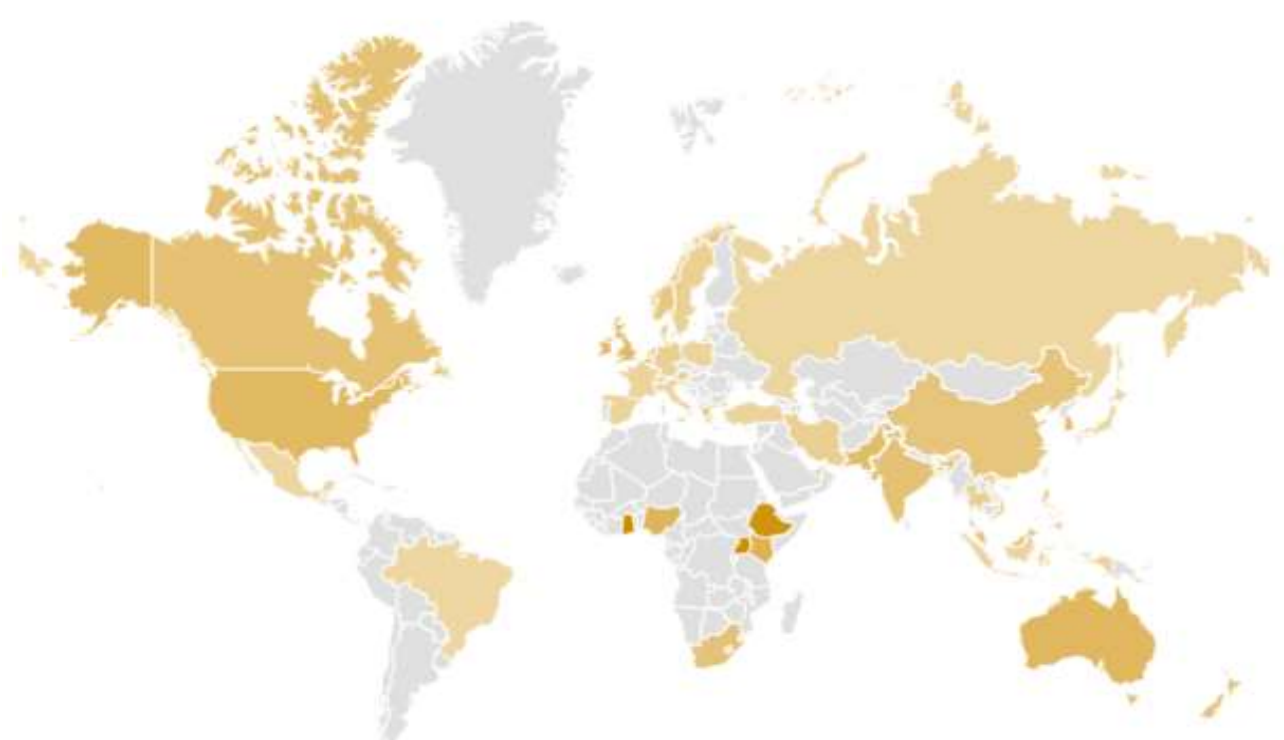

Figure 5. Topographic map of the world, showing the number of requests for the term "energy policy" (2004-2019). (Color intensity depends on the percentage of queries)

Source: built by the author based on data (Ziabina, 2021) and Google Trends.

The analysis also revealed the top 10 countries whose populations are most interested in energy policy issues (Table 3).

Table 3. The level of interest in the world in terms of "energy policy" (2004-2019)

\begin{tabular}{|c|c|c|}
\hline № & Country & Interest level, \% \\
\hline 1 & Ghana & 100 \\
\hline 2 & Uganda & 97 \\
\hline 3 & Ethiopia & 52 \\
\hline 4 & Kenya & 46 \\
\hline 5 & Nigeria & 43 \\
\hline 6 & Australia & 40 \\
\hline 7 & Ireland & 40 \\
\hline 8 & United States & 39 \\
\hline 9 & UK & 38 \\
\hline
\end{tabular}

Source: built by the author based on data (Ziabina, 2021) and Google Trends.

According to the analysis of the intensity of interest in the study of selected terms - "energy efficiency", "sustainable development", and "energy policy" - Ukraine has the following meanings:

- level of interest in the term "energy efficiency" $-26 \%$;

- level of interest in the term "sustainable development" - 12\%;

- level of interest in the term "energy policy" $-10 \%$.

The analysis revealed the sectoral structure of research areas and identified the dominant subject areas in which scientists explore the energy efficiency of the national economy (Fig. 6). 


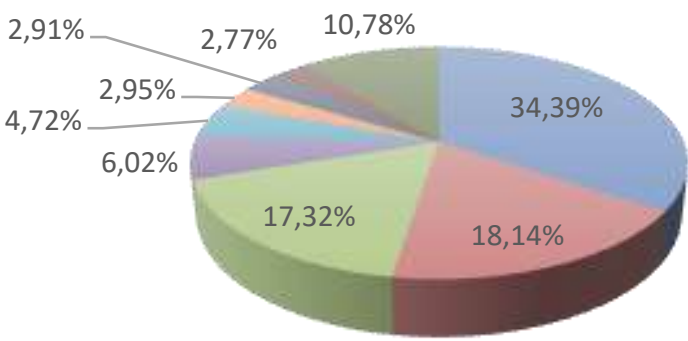

$\begin{array}{ll}\text { Ecology } & \text { Technical sciences } \\ \text { Energy } & \text { Business, management and accounting } \\ \square \text { Social sciences } & \text { Earth and planet sciences } \\ \square \text { Economics, econometrics and finance } & \text { - Chemical engineering } \\ \square \text { Others } & \end{array}$

Figure 6. Subject areas within which the scientific community researches energy efficiency issues

Source: built by the author based on Scopus and Web of Science data.

In particular, it should be noted that the ranking by the volume of published research is the subject area - ecology (34.39\% of all published research on the search for "energy efficiency" in scientometric databases Scopus and Web of Science). Accordingly, the scientific society once again cites the indisputable facts of a direct correlation between energy efficiency and the state of the environment. In second place - technical sciences (18.14\%), and in third place - the study of energy efficiency in the energy sector.

To analyze the demand for relevant scientific achievements, an array of bibliometric data was formed and ranked according to the number of citations, resulting in the top 10 most cited scientific publications in scientometric databases Scopus and Web of Science (Table 4).

Table 4. Top 10 most cited researchers in the field of energy efficiency from 2000 to 2020

\begin{tabular}{|c|c|c|c|c|c|c|}
\hline № & Article title & $\begin{array}{l}\text { Number of } \\
\text { citations }\end{array}$ & Citation index & Author & $\begin{array}{c}\text { Year of } \\
\text { publication }\end{array}$ & Publisher \\
\hline 1 & 2 & 3 & 4 & 5 & 6 & 7 \\
\hline 1 & $\begin{array}{l}\text { Energy efficiency and consumption - } \\
\text { the rebound effect - a survey }\end{array}$ & 1075 & 939 & $\begin{array}{l}\text { Greening L. A., } \\
\text { Greene D.L., } \\
\text { Difiglio C. }\end{array}$ & 2000 & Energy Policy \\
\hline 2 & $\begin{array}{c}\text { Total-factor energy efficiency of } \\
\text { regions in China }\end{array}$ & 784 & 485 & $\begin{array}{l}\text { Hu J.-L., Wang } \\
\text { S.-C. } \\
\end{array}$ & 2006 & Energy Policy \\
\hline 3 & $\begin{array}{l}\text { Review of passive PCM latent heat } \\
\text { thermal energy storage systems } \\
\text { towards buildings' energy efficiency }\end{array}$ & 533 & 233 & $\begin{array}{l}\text { Soares N., Costa } \\
\text { J. J., Gaspar A. } \\
\text { R., } \\
\text { Santos P. }\end{array}$ & 2013 & $\begin{array}{l}\text { Energy and } \\
\text { Buildings }\end{array}$ \\
\hline 4 & $\begin{array}{l}\text { Energy Efficiency in the Future } \\
\text { Internet: A Survey of Existing } \\
\text { Approaches and Trends in Energy- } \\
\text { Aware Fixed Network Infrastructures }\end{array}$ & 521 & 399 & $\begin{array}{l}\text { Bolla R., Bruschi } \\
\text { R., Davoli F., } \\
\text { Cucchietti F. }\end{array}$ & 2011 & $\begin{array}{c}\text { IEEE } \\
\text { Communications } \\
\text { Surveys \& } \\
\text { Tutorials }\end{array}$ \\
\hline 5 & Is There an Energy Efficiency Gap? & 334 & 332 & $\begin{array}{l}\text { Allcott H., } \\
\text { Green-stone M. }\end{array}$ & 2012 & $\begin{array}{c}\text { Journal of } \\
\text { Economic } \\
\text { Perspectives } \\
\end{array}$ \\
\hline 6 & $\begin{array}{c}\text { Putting renewables and energy } \\
\text { efficiency to work: How many jobs } \\
\text { can the clean energy industry generate } \\
\text { in the US? }\end{array}$ & 327 & 241 & $\begin{array}{l}\text { Wei M., Patadia } \\
\text { S., Kam- men } \\
\text { D. M. }\end{array}$ & 2010 & Energy Policy \\
\hline
\end{tabular}


Table 4 (cont.). Top 10 most cited researchers in the field of energy efficiency from 2000 to 2020

\begin{tabular}{|c|c|c|c|c|c|c|}
\hline № & Article title & $\begin{array}{c}\text { Number of } \\
\text { citations }\end{array}$ & Citation index & Author & $\begin{array}{c}\text { Year of } \\
\text { publication }\end{array}$ & Publisher \\
\hline 7 & $\begin{array}{c}\text { Polices for increasing energy } \\
\text { efficiency: Thirty years of experience } \\
\text { in OECD countries }\end{array}$ & 301 & 207 & $\begin{array}{c}\text { Geller H., Harrin- } \\
\text { gton P., Rosen- } \\
\text { feld A. H., } \\
\text { Tanishi- ma S., } \\
\text { Unander F. }\end{array}$ & 2006 & Energy Policy \\
\hline 8 & $\begin{array}{c}\text { Chinese regional industrial energy } \\
\text { efficiency evaluation based on a DEA } \\
\text { model of fixing non-energy inputs }\end{array}$ & 284 & 178 & $\begin{array}{c}\text { Shi G.-M., Bi J., } \\
\text { Wang J.-N. }\end{array}$ & 2010 & Energy Policy \\
\hline 9 & $\begin{array}{c}\text { Jevons' Paradox revisited: The } \\
\text { evidence for backfire from improved } \\
\text { energy efficiency }\end{array}$ & 282 & 203 & Sorrell S. & 2009 & Energy Policy \\
\hline 10 & Energy efficiency - a critical view & 282 & 169 & Herring H. & 2006 & Energy \\
\hline
\end{tabular}

Source: formed by the author on the basis of (Ziabina, 2021) and Scopus database.

Table 4 shows the titles of articles, number and index of citations, the impact of the cited weighted field (reflects the quality of citation of relevant scientific work with similar works, taking into account the year of publication, type of scientific work and field of knowledge in which the study is published), authors, year of publication and publisher.

In the first place in terms of the number of citations and with the most extensive index of citations, the article by Lorna Greening, David Green and Carmen Difiglio (Greening, Greene, \& Difiglio, 2000), which reflects a bibliographic and empirical study of the dependence of energy efficiency and consumption in the United States. The authors analyzed the most promising areas of energy efficiency and presented the results of empirical evidence for responsible consumption at the micro and macro levels of energy resources as an alternative way to increase energy efficiency.

In the second-cited scientific publication (Table 4), the authors (Hu, \& Wang, 2006) analyzed the energy efficiency of twenty-five regions of China regarding the overall energy efficiency ratio and found a significant direct relationship between the level of energy efficiency and economic growth.

In third place in terms of citations is a scientific article related to the study of passive storage systems for thermal energy with hidden thermal energy to increase the energy efficiency of buildings (Soares, Costa, Gaspar, \& Santos, 2013).

Scientific works by R. Bolla, R. Baidjolov, F. Davoli (Bolla, Bruschi, Davoli, \& Cucchietti, 2011), devoted to the study of prospects for energy consumption by future generation power grids and a detailed review of new technologies and projects, can be implemented in the economic sphere and reconstruction infrastructure of the country to reduce the carbon pressure on the environment and increase the energy efficiency of the national economy.

Olcott Hunt and Michael Greenstone, in their scientific publication "Are there gaps in energy efficiency?", Which is ranked fifth among the most cited publications on the energy efficiency of the national economy (Allcott, \& Greenstone, 2012), explore possible options for energy development, efficiency from different scientific angles. In particular, the authors consider increasing the energy efficiency level through consumer savings, provided that reducing household income or the development of energy efficiency through solid investment.

Scientific publications (Geller, Harrington, Rosenfeld, Tanishima, \& Unander, 2006; Herring, 2006; Shi, Bi, \& Wang, 2010; Sorrell, 2009; Wei, Patadia, Kammen, 2010) investigate the positive and negative effects of rapid growth, energy efficiency and the question of how energy efficiency policy and the introduction of renewable energy sources affect the national economy.

As part of the study of energy efficiency in the context of the green energy transition, four scientific alliances were identified (Fig. 7): 
- the first scientific alliance (green), with fourteen scientists from China, Switzerland and Singapore;

- the second scientific alliance (blue) has the most prominent geographical structure and has eleven scientists from China, the United States, Austria and Denmark;

- the third scientific alliance (red), which includes fourteen scientists from three countries (Taiwan, China, USA).

The fourth scientific alliance (yellow), which has the smallest number of scientists ( 7 scientists), covers countries like China, the USA, and Canada.

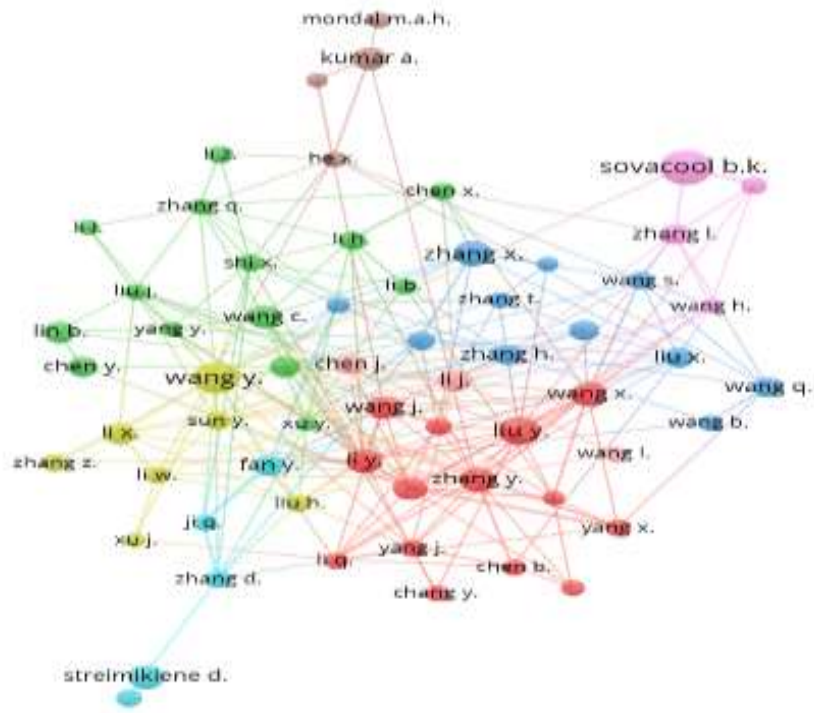

Figure 7. Visualization map of international scientific alliances for energy efficiency research of the national economy based on the results of analysis of citations in scientific publications indexed by Scopus and Web of Science databases

Source: built by the author on the basis of (Ziabina, 2021) and Scopus and Web of Science databases using VOSviewer software.

Let us consider in more detail the geographical structure of scientific publications on the study of energy efficiency of the national economy, indexed by the Web of Science database (Fig. 8). From the visualization map (Fig. 8) it is possible to note the top 10 countries in the world, whose scientists are actively publishing their scientific work, indexed by the scientometric database Web of Science:

1) China - $19.974 \%$;

2) the United States of America - 18.692\%;

3) the Great Britain $-5.633 \%$;

4) Germany $-5.231 \%$;

5) Italy $-4.145 \%$;

6) India-3.638\%;

7) South Korea $-3.515 \%$;

8) Japan $-3.218 \%$;

9) Spain -3,049\%;

10) Canada $-3.045 \%$. 


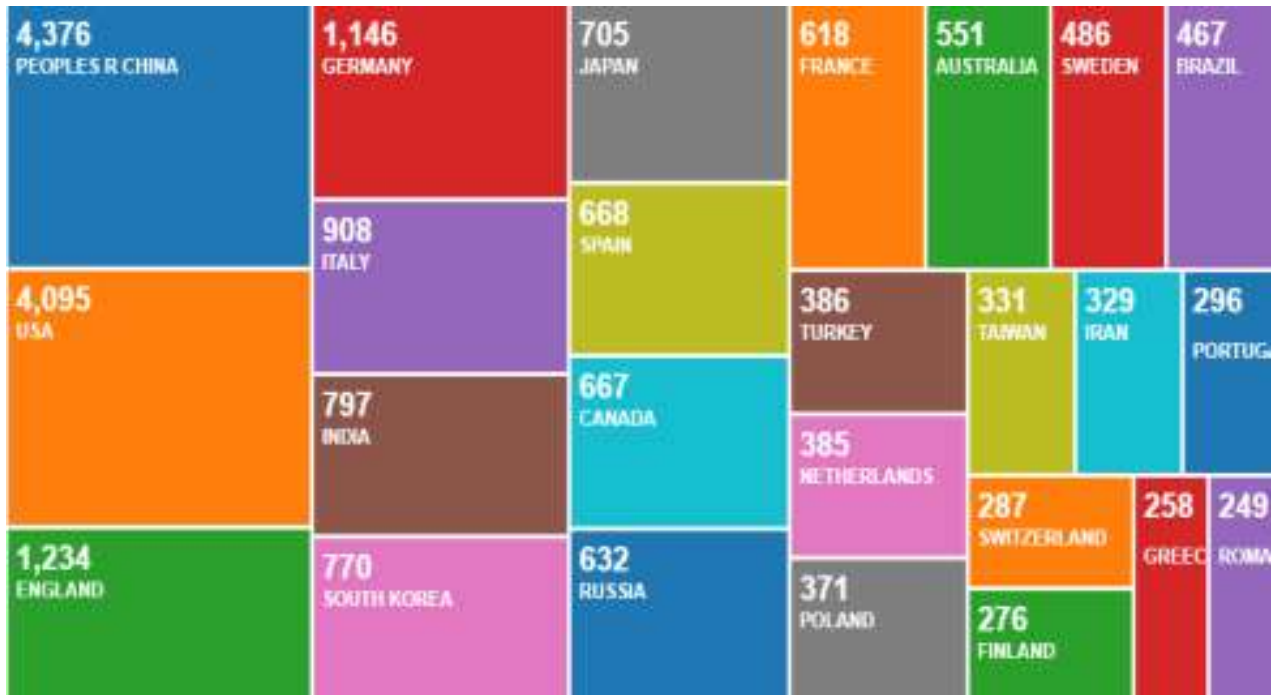

Figure 8. Visual map of the results of the bibliometric analysis to identify countries whose scientists during 1990-2020 were the most active in research on the energy efficiency of the national economy

Source: built by the author based on (Ziabina, 2021) and databases Scopus and Web of Science.

At the same time, other countries have a share of publications of 3\% and below. These statistics confirm the hypothesis of invariability of relevance in energy efficiency research of the national economy in developing countries and need an appropriate vector of development and the G7 ("G7"). It proves that energy efficiency needs to be constantly studied, improved, and analyzed to continuously obtain favourable results for the functioning of the national economy and maintain energy security and independence.

To determine promising areas of research on energy efficiency of the country, a co-occurrence analysis was performed using VOSviewer software. The results of the analysis allowed to cluster the interdisciplinary relationships of research on the theory of energy efficiency of the national economy, which is shown in Figure 9.

The results of the analysis of the density of relationships between keywords revealed six interdisciplinary clusters of research on energy efficiency in the context of the transition of the national economy to a carbon-neutral model of its development (Fig. 9):

- Red cluster 1 "State regulation of the energy sector", which combines 309 terms related to the study of state regulation of the national economy's energy sector. The keyword in the cluster is "energy policy", the frequency of using the keyword in the sample of scientific publications is 2,563, and the density of links between the formed example of keywords is 915 ;

- Green cluster 2, "Sustainable development of the energy sector of the national economy", combines 188 terms related to the study of sustainable development of the energy sector. The keyword in the cluster is "sustainable development", the frequency of use of the keyword in the sample of scientific publications is 2,463 , and the density of links between the formed example of keywords is 915 ;

- Blue cluster 3, "Impact of the energy sector on the environment", combines 182 terms related to studying the energy sector's impact on the environment. The keyword in the cluster is "fossil fuel", the frequency of keyword use in the sample of scientific publications is 633, and the density of links between the formed example of keywords is 865 ;

- Yellow cluster 4 "Tools for improving the national economy's energy efficiency", which combines 134 terms related to the study of tools for improving the energy efficiency of the national economy. The keyword in the cluster is "energy efficiency", the frequency of using the keyword in the sample of scientific publications is 1,528, and the density of links between the formed example of keywords is 911. 


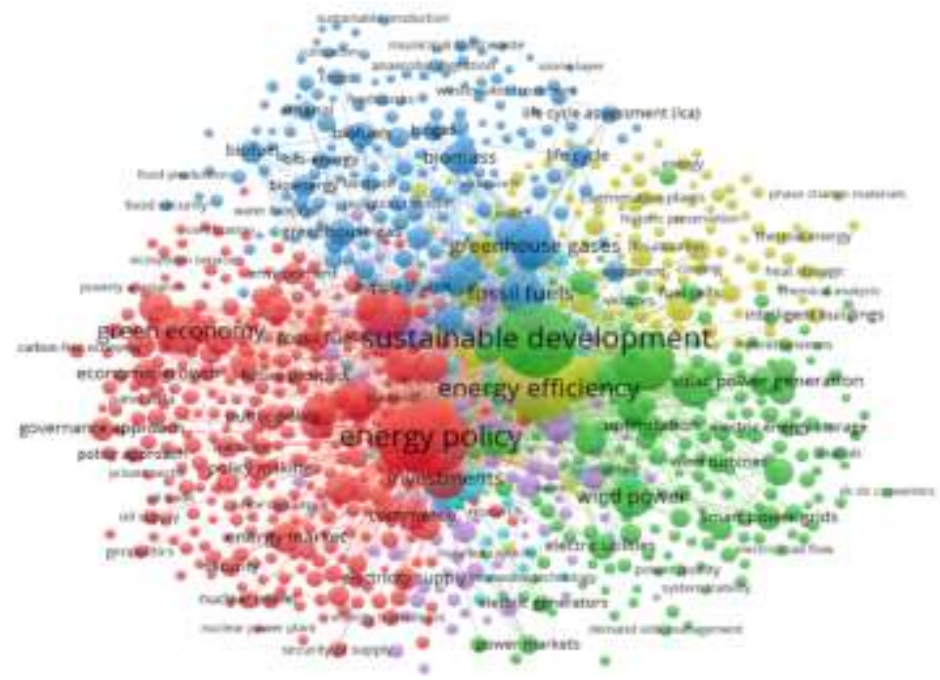

Figure 9. Clustering of identified interdisciplinary relationships of research on the theory of energy efficiency of the national economy

Source: built by the author based on Scopus and Web of Science databases using VOSviewer software.

- Purple cluster 5 "Green technologies to improve the energy efficiency of the national economy", which combines 80 terms related to the study of the implementation of green technologies to improve the national economy's energy efficiency. The keyword in the cluster is "sustainable energy", the frequency of use of the keyword in the sample of scientific publications is 457 , and the density of links between the formed example of keywords is 801 ;

- blue cluster 6 "Smart energy networks in the energy sector of the national economy", which combines 27 terms related to the study of the development of intelligent energy networks in the energy sector of the national economy. The keyword in the cluster is "smart grids", the frequency of use of the keyword in the sample of scientific publications is 325, and the density of links between the formed example of keywords is 695 .

All selected clusters (Fig. 9) have a high density of interconnection, which confirms the interdisciplinary nature of the theory of energy efficiency of the national economy.

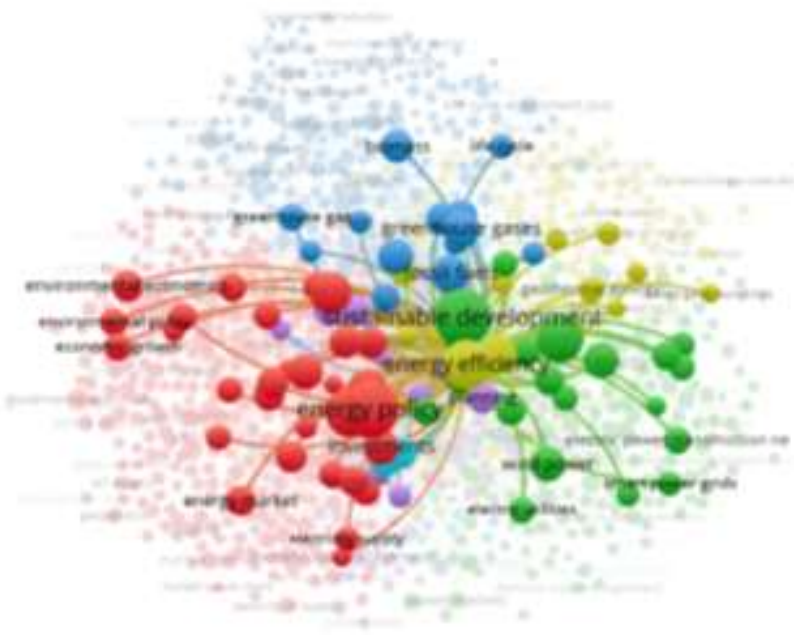

Figure 10. Visualization map of the identified interdisciplinary relationships of energy efficiency between the studied clusters

Source: built by the author based on Scopus and Web of Science databases using VOSviewer software. 
Bibliometric analysis using VOSViewer v. 1.6.10 allowed to identify and visualize the temporal measurement of the six stages of evolution of the theory of energy efficiency of the national economy:

1. until 2013, research was focused on studying the problems of the energy sector of the national economy and the study of the negative impact of the concentration of greenhouse gases in the environment;

2. in 2013-2014, research focused on energy saving as a new vector of state policy to ensure energy security of the national economy;

3. in 2014-2015, research was focused on the formation of determinants of improving the energy efficiency of the national economy in the context of achieving sustainable development goals;

4. in 2015-2016, research focused on tools for the dissemination of green energy and assessing the effectiveness of the introduction of renewable energy sources to increase the energy efficiency of the national economy;

5. in 2016-2017, scientists focused on the study of energy services, the effectiveness of attracting green investment in energy-efficient projects;

6. from 2017 until today, the scientific society pays close attention to the determinants of energy efficiency in the context of the transition of the national economy to a carbon-neutral model of its development.

\section{Conclusion}

The results of trend analysis of the evolution of energy efficiency theory of the national economy using Google Trends, Scopus Tools Analysis, and Web of Science Results Analysis revealed the convergence of trends between queries in the Google search engine and scientometric databases Scopus and Web of Science. A sample of 48,888 publications and 21,725 search queries (keywords "energy policy", "energy efficiency", "sustainable development") was generated for analysis. It is established that 2014 is a turning point in the level of interest of society and the scientific community in energy efficiency of the national economy, as evidenced by a significant increase in energy efficiency publications indexed by scientometric databases Scopus and Web of Science, as well as the number of searches - users. This growth is due to the development and approval by the UN General Assembly of the Action Plan "Transforming our world: Agenda for sustainable development until 2030", one of the goals of which is to increase the energy efficiency of the national economy.

Bibliometric analysis using VOSViewer v. 1.6 .10 allowed to identify and visualize the temporal measurement of the six stages of evolution of the theory of energy efficiency of the national economy:

1. until 2013, research was focused on studying the problems of the energy sector of the national economy;

2. in 2013-2014 - on energy saving as a new vector of the state policy of ensuring energy security of the national economy;

3. in 2014-2015 - on the determinants of improving the energy efficiency of the national economy in the context of achieving sustainable development goals;

4. in 2015-2016 - on the instruments of green energy dissemination to increase the energy efficiency of the national economy;

5. in 2016-2017 - on the study of energy services, attracting green investments in energy-efficient projects;

6. from 2017 to the present - on the determinants of energy efficiency in the context of the transition of the national economy to a carbon-neutral model of its development.

Scientific alliances that explore energy efficiency within a green energy transition concept are international and non-geographically localized. The largest are Alliances 1 and 3, which bring together scientists from China, the United States, Switzerland and Taiwan.

The results of the analysis of the density of relationships between keywords revealed six interdisciplinary clusters of research on energy efficiency in the context of the transition of the national economy to a carbon-neutral model of its development:

- cluster 1 combines research on state regulation of the energy sector of the national economy;

- cluster 2 - on sustainable development of the energy sector of the national economy;

- cluster 3 - on the impact of the energy sector on the environment;

- cluster 4 - on instruments for improving the energy efficiency of the national economy;

- cluster 5 - on the implementation of green technologies to improve the energy efficiency of the national 
economy;

- cluster 6 - on the development of intelligent energy networks in the national economy's energy sector.

All selected clusters have a high density of interconnection, which confirms the interdisciplinary nature of the theory of energy efficiency of the national economy.

Funding: The research was funded by the grants from the Ministry of Education and Science of Ukraine (Modeling mechanisms for minimizing energy efficiency gaps in the context of the Sustainable Development Goals: a communicative network of stakeholder interaction, № 0120U102002; Simulation modeling of influence's trajectory of behavioral attractors on macroeconomic stability: the role of transparency and public trust, № 0121U100469; Green investing: cointegration model of transmission ESG effects in the chain "green brand of Ukraine - social responsibility of business”, № 0121U100468).

Author Contributions: conceptualization, Yevheniia Ziabina, Yevhen Kovalenko; methodology, Yevheniia Ziabina; validation, Yevheniia Ziabina, Yevhen Kovalenko; formal analysis, Yevhen Kovalenko; investigation, Yevheniia Ziabina; resources, Yevheniia Ziabina, Yevhen Kovalenko; data curation, Yevhen Kovalenko; writing original draft preparation, Yevheniia Ziabina, Yevhen Kovalenko; writing review and editing, Yevheniia Ziabina, Yevhen Kovalenko; visualization, Yevheniia Ziabina; supervision, Yevheniia Ziabina, Yevhen Kovalenko; project administration, Yevheniia Ziabina, Yevhen Kovalenko.

\section{References}

1. Allcott, H., \& Greenstone, M. (2012). Is There an Energy Efficiency Gap? Journal of Economic Perspectives, 26(1), 3-28. DOI: 10.1257/jep.26.1.3.

2. Bolla, R., Bruschi, R., Davoli, F., \& Cucchietti, F. (2011). Energy Efficiency in the Future Internet: A Survey of Existing Approaches and Trends in Energy-Aware Fixed Network Infrastructures. IEEE Communications Surveys \& Tutorials, 13(2), 223-244. DOI: 10.1109/surv.2011.071410.00073.

3. Bonamigo, A., Mendes, D. (2019). Value Co-creation and Leadership: An Analysis Based on the Business Ecosystem Concept. Business Ethics and Leadership, 3(4), 66-73. DOI: http://doi.org/10.21272/bel.3(4).6673.2019.

4. Bozhkova, V. V., Ptashchenko, O. V., Saher, L. Y., \& Syhyda, L. O. (2018). Transformation of marketing communications tools in a globalizing environment. Marketing and innovation management, 1, 73-82. DOI: 10.21272/mmi.2018.1-05.

5. Caruso, G., Colantonio, E., \& Gattone, S. A. (2020). Relationships between Renewable Energy Consumption, Social Factors, and Health: A Panel Vector Auto Regression Analysis of a Cluster of 12 EU Countries. Sustainability, 12(7), 2915. DOI: 10.3390/su12072915.

6. Chygryn, O., Bilan, Y., \& Kwilinski, A. (2020). Stakeholders of Green Competitiveness: Innovative Approaches for Creating Communicative System. Marketing and Management of Innovations, 3, 358-370. DOI: http://doi.org/10.21272/mmi.2020.3-26.

7. De la Cruz-Lovera, C., Perea-Moreno, A.-J., de la Cruz-Fernández, J.-L., Alvarez-Bermejo, J., \& ManzanoAgugliaro, F. (2017). Worldwide Research on Energy Efficiency and Sustainability in Public Buildings. Sustainability, 9(8), 1294. DOI: 10.3390/su9081294.

8. El Amri, A., Boutti, R., Oulfarsi, S., Rodhain, F., Bouzahir, B. (2020). Carbon financial markets underlying climate risk management, pricing and forecasting: Fundamental analysis. Financial Markets, Institutions and Risks, 4(4), 31-44. DOI: https://doi.org/10.21272/fmir.4(4).31-44.2020

9. Geller, H., Harrington, P., Rosenfeld, A. H., Tanishima, S., \& Unander, F. (2006). Polices for increasing energy efficiency: Thirty years of experience in OECD countries. Energy Policy, 34(5), 556-573. DOI: 10.1016/j.enpol.2005.11.010.

10.Greening, L. A., Greene, D. L., \& Difiglio, C. (2000). Energy efficiency and consumption - the rebound effect - a survey. Energy Policy, 28(6-7), 389-401. DOI: 10.1016/s0301-4215(00)00021-5.

11.He, Shuquan (2019). The Impact of Trade on Environmental Quality: A Business Ethics Perspective and Evidence from China. Business Ethics and Leadership, 3(4), 43-48. DOI: http://doi.org/10.21272/bel.3(4).43$\underline{48.2019 .}$ 
SocioEconomic Challenges, Volume 5, Issue 1, 2021 ISSN (print) - 2520-6621, ISSN (online) - 2520-6214

12.Herring, H. (2006). Energy efficiency - a critical view. Energy, 31(1), 10-20. DOI: 10.1016/j.energy.2004.04.055.

13.Hu, J.-L., \& Wang, S.-C. (2006). Total-factor energy efficiency of regions in China. Energy Policy, 34(17), 3206-3217. DOI: 10.1016/j.enpol.2005.06.015.

14.K. B. Kouassi. (2018). Public Spending and Economic Growth in Developing Countries: a Synthesis. Financial Markets, Institutions and Risks, 2(2), 22-30. DOI: 10.21272/fmir.2(2).22-30.2018

15.Karakasis, V. P. (2017). The impact of "policy paradigms" on energy security issues in protracted conflict environments: the case of Cyprus. SocioEconomic Challenges, 1(2), 5-18. DOI: http://doi.org/10.21272/sec.1(2).5-18.2017.

16. Korobets O., Panchenko V., Harust Yu., Us Ya., \& Pavlyk V. (2020). Energy-Efficient Innovations: Marketing, Management and Law Supporting. Marketing and Management of Innovations, 1, 256-264. DOI: http://doi.org/10.21272/mmi.2020.1-21.

17.Liulov, O., Pimonenko, T., Stoyanets, N., \& Letunovska, N. (2019). Sustainable Development of Agricultural Sector: Democratic Profile Impact Among Developing Countries. Research in World Economy. 10 (4), 97 105. DOI: $10.5430 /$ rwe.v10n4p97.

18.Lyulyov, O. V., \& Pimonenko, T. V. (2017). Lotka-Volterra model as an instrument of the investment and innovative processes stability analysis. Marketing and Management of Innovations, 1, 159-169. DOI: http://doi.org/10.21272/mmi.2017.1-14.

19. Mačaitytè, I., Virbašiūtė, G. (2018). Volkswagen Emission Scandal and Corporate Social Responsibility - A Case Study. Business Ethics and Leadership, 2(1), 6-13. DOI: 10.21272/bel.2(1).6-13.2018.

20.Molotok, I. (2020). Analysis Of The Relevance Of Fiscal Decentralization In Ensuring Country Investment Attractiveness. SocioEconomic Challenges, 4(2), 99-105. https://doi.org/10.21272/sec.4(2).99-105.2020.

21.Nasr, A. K., Kashan, M. K., Maleki, A., Jafari, N., \& Hashemi, H. (2020). Assessment of Barriers to Renewable Energy Development Using Stakeholders Approach. Entrepreneurship and Sustainability Issues, 7(3), 2526-2541. Available at: https://ideas.repec.org/a/ssi/jouesi/v7y2020i3p2526-2541.html.

22. On the objective of sustainable development of Ukraine till 2030: President of Ukraine Decree number 722/2019 Adapted from https://www.president.gov.ua/documents/7222019-29825.

23.Palienko M., Lyulyov O., Denysenko P. (2017). Fiscal Decentralisation as a Factor of Macroeconomic Stability of the Country. Financial Markets, Institutions and Risks, 1(4), 74-86. DOI: 10.21272/fmir.1(4).74$\underline{86.2017 .}$

24.Palienko, M., Lyulyov, O. (2018). The Impact of Social Factors on Macroeconomic Stability: Empirical Evidence for Ukraine and European Union Countries. SocioEconomic Challenges, 2(1), 103-116. DOI: $10.21272 / \mathrm{sec} .2(1) .103-116.2018$

25.Panchenko, V., Harust, Yu., Us, Ya., Korobets, O., \& Pavlyk, V. (2020). Energy-Efficient Innovations: Marketing, Management and Law Supporting. Marketing and Management of Innovations, 1, 256-264. DOI: 10.21272/mmi.2020.1-21.

26.Pavlyk, V. (2020). Assessment of green investment impact on the energy efficiency gap of the national economy. Financial Markets, Institutions and Risks, 4(1), 117-123. DOI: http://doi.org/10.21272/fmir.4(1).117-123.2020.

27.Pimonenko, T, Chygryn, O., \& Luylov, O. (2018). Green Entrepreneurship as an Integral Part of the National Economy Convergence. In O. Prokopenko, V. Omelyanenko, Yu. Ossik. (Eds.), National Security \& Innovation Activities: Methodology, Policy and Practice: monograph (pp. 358-365). Ruda Śląska: Drukarnia i Studio Graficzne Omnidium. Available at: https://essuir.sumdu.edu.ua/bitstream/123456789/67787/1/Propokenko_monograf.pdf.

28.Pimonenko, T. (2018). Green investment as a driving force for the dissemination of energy efficient projects: the EU experience for Ukraine. Economic space, 139, 229-241. Available at: http://nbuv.gov.ua/UJRN/ecpros $2018 \quad 13920$.

29.Shi, G.-M., Bi, J., \& Wang, J.-N. (2010). Chinese regional industrial energy efficiency evaluation based on a DEA model of fixing non-energy inputs. Energy Policy, 38 (10), 6172-6179. DOI: 10.1016/j.enpol.2010.06.003.

30.Sineviciene, L., Sotnyk, I., \& Kubatko, O. (2017). Determinants of energy efficiency and energy consumption 
of Eastern Europe post-communist economies. Energy \& Environment, 28 (8), 870-884. DOI: $10.1177 / 0958305 \times 17734386$.

31.Soares, N., Costa, J. J., Gaspar, A. R., \& Santos, P. (2013). Review of passive PCM latent heat thermal energy storage systems towards buildings' energy efficiency. Energy and Buildings, 59, 82-103. DOI: 10.1016/j.enbuild.2012.12.042.

32.Sorrell, S. (2009). Jevons' Paradox revisited: The evidence for backfire from improved energy efficiency. Energy Policy, 37(4), 1456-1469. DOI: 10.1016/j.enpol.2008.12.003.

33. Taliouris, E., Trihas, N. (2017). Public Policy for Corporate Social Responsibility and Governance for Sustainable Tourism Development in Greece. Business Ethics and Leadership, 1(4), 49-57. DOI: 10.21272/bel.1(4).49-57.2017

34.Tovmasyan, G. (2019). Assessing some indicators of tourism sustainability: case study from Armenia. SocioEconomic Challenges, 3(1), 127-136. DOI: http://doi.org/10.21272/sec.3(1).127-136.2019.

35.Uzar, U. (2020). Political economy of renewable energy: Does institutional quality make a difference in renewable energy consumption? Renewable Energy. DOI: 10.1016/j.renene.2020.03.172.

36. Wei, M., Patadia, S., \& Kammen, D. M. (2010). Putting renewables and energy efficiency to work: How many jobs can the clean energy industry generate in the US? Energy Policy, 38(2), 919-931. DOI: 10.1016/j.enpol.2009.10.044.

37. Yiu, L., Saner, R., Bardy, R. (2020). Collective Action on Public Goods for Sustainable Development: Ethics in Action. Business Ethics and Leadership, 4(4), 14-27. DOI: https://doi.org/10.21272/bel.4(4).14-27.2020

38.Z. Khadidja, B. Bachir. (2018). The Algerian bank between ecoregulations and development of customer loyalty. Financial Markets, Institutions and Risks, 2(2), 93-99. DOI: 10.21272/fmir.2(2).93-99.2018.

39.Ziabina, Ye., \& Pimonenko, T. (2020) The Green Deal Policy for Renewable Energy: A Bibliometric Analysis. Virtual Economics. 3(4), 147-168. Available at: https://virtualeconomics.eu/index.php/VE/article/view/89. 